\title{
Effect of pore geometry of mesoporous supports on catalytic performances in methane reforming
}

\author{
Joy Tannous, Leila Karam, Marie-Nour Kaydouh, \\ Henri El Zakhem, Nissrine El Hassan* \\ Department of Chemical Engineering \\ University Of Balamand \\ Amioun, El Koura, Lebanon \\ nissrine.hassan@balamand.edu.lb
}

\author{
Sandra Casale \\ Laboratoire de Réactivité de Surface (LRS) \\ Université Pierre et Marie Curie, Paris 6 \\ Paris, France
}

\begin{abstract}
Catalysts prepared using three dimensional SBA16 silica support (composed of micropores and cage-like mesopores) were tested in the reaction of methane dry reforming, in comparison with $2 D$ hexagonal mesoporous SBA-15 support. The samples were evaluated by $N_{2}$ sorption and $X$-Ray diffraction (XRD) for the assessment of their textural and structural properties. The reducibility was characterized by temperature programmed reduction (TPR). The catalytic performances were evaluated in methane dry reforming and spent catalysts (after reaction) were characterized for the evaluation of sintering and coke formation by TPH/MS, XRD and HR-TEM.
\end{abstract}

Keywords-Mesoporous silica; methane dry reforming; pore geometry; sintering resistance

\section{INTRODUCTION}

Natural gas can be converted to liquid hydrocarbons through two major steps; the first one is its conversion into syngas, which is then transformed by Fischer-Tropsch synthesis (FTS) into liquid hydrocarbons. The first step can be accomplished by steam reforming, partial oxidation, autothermal reforming or other reactions. An alternative way for this conversion is the dry reforming of methane DRM $\left(\mathrm{CH}_{4(\mathrm{~g})}+\mathrm{CO}_{2(\mathrm{~g})} \rightarrow 2 \mathrm{CO}_{(\mathrm{g})}+2 \mathrm{H}_{2(\mathrm{~g})}\right)$ that has additional advantages compared to the previously cited reactions: consumption of the greenhouse gas $\mathrm{CO} 2$ and production of a ratio $\mathrm{H}_{2}: \mathrm{CO}$ close to one (good for increased selectivity in FTS).

DRM was performed over different types of catalysts especially noble metal catalysts like $\mathrm{Pt}, \mathrm{Ru}, \mathrm{Rh}, \mathrm{Pd}$ and Ir that showed excellent activity and stability during reaction but these catalysts are expensive and rarely found. Nickel was as active as noble metals and thus became a promising alternative, especially that it is cheap and readily available [1-4]. However, Ni particles could still suffer from sintering or coke formation at high temperature, which drastically affects the catalytic performances. Consequently, researchers have intensified their efforts to solve these problems through several procedures such as incorporation of small amount of rare and alkaline earth metals over nickel based catalysts [5-7] or changing supports type and enhancing metal-support interaction $[8,9]$.
Recent studies have shown that mesoporous SBA-15 silica support is promising for the confinement and stabilization of nickel in DRM reaction [10,11]. The addition of ceria to $\mathrm{Ni} / \mathrm{SBA}-16$ catalysts was studied by Zhang et al. [12] and the results showed that NiCe/SBA-16 was more stable, exhibiting higher conversion than Ni/SBA-16 in DRM. The studies in the literature were conducted under different experimental conditions (varying catalyst preparation and catalytic test conditions) and a direct comparison between SBA-15 and SBA-16 is not reported. Nevertheless, it is important to compare the two supports in order to check if the geometry of such materials can affect the performances of the resulting catalysts in the challenging DRM reaction.

\section{EXPERIMENTAL}

\section{A. Catalysts preparation}

Evaporation induced self-assembly [13,14] and sol-gel $[15,16]$ methods are commonly used for the preparation of mesoporous materials. In this work, SBA-16(1) support was prepared using sol-gel technique following an established procedure of Cheng et al. [17]. In details, $5.66 \mathrm{~g}$ of the tri-block copolymer F-127 ( $\left.\mathrm{PEO}_{106} \mathrm{PPO}_{70} \mathrm{PEO}_{106}\right)$ (Sigma-Aldrich, $\mathrm{P} 2443$ ) were added to $250 \mathrm{ml}$ of a $2 \mathrm{M} \mathrm{HCl}$. The mixture was stirred for 2 hours at $30^{\circ} \mathrm{C}$. Then $19.81 \mathrm{~g}$ of TEOS (SigmaAldrich, 86578) were used as the silica precursor and the resultant mixture was stirred for 20 hours before filtration, washing with distilled water and drying in air at $110^{\circ} \mathrm{C}$ overnight. The support was next calcined at $500^{\circ} \mathrm{C}$ for 9 hours (at $2^{\circ} \mathrm{C} \cdot \mathrm{min}^{-1}$ ).

SBA-16(2) support was prepared as reported by Dos Santos et al. [18]. $4 \mathrm{~g}$ of F-127 were added to $0.4 \mathrm{M} \mathrm{HCl}$. After complete dissolution, co-surfactant butanol (Sigma-Aldrich, 33065) was added and stirred at $45^{\circ} \mathrm{C}$ for 1 hour. This was followed by the addition of $19.3 \mathrm{~g}$ of TEOS and vigorous stirring at $45^{\circ} \mathrm{C}$ for another 24 hours. The obtained white precipitate was then filtered, dried in air at $100^{\circ} \mathrm{C}$ for 24 hours and then calcined at $550^{\circ} \mathrm{C}$ for 2 hours $\left(\right.$ at $\left.2^{\circ} \mathrm{C} \cdot \mathrm{min}^{-1}\right)$.

Commercial SBA-15 mesostructured silica was used as the third support in this study (Sigma Aldrich, 777242). 
Impregnation of nickel $(5 \mathrm{wt} \%)$ on the three different supports was performed following "two solvents" loading method described elsewhere [19] and the calcination based on the optimized conditions reported in previous work [11]. The resulting samples were labeled as Ni/SBA-16(1), Ni/SBA16(2), and Ni/SBA-15.

\section{B. Catalysts characterization}

The ASAP 2020 apparatus from Micromeritics was used to obtain the $\mathrm{N}_{2}$-sorption isotherms at $-196^{\circ} \mathrm{C}$ after proper degas under vacuum at $250^{\circ} \mathrm{C}$ for 2 hours.

$\mathrm{X}$-Ray diffraction peaks and results were performed on a PANanalytical $\mathrm{X}^{\prime} \mathrm{Pert}^{3}$ diffractometer using $\mathrm{Cu} \mathrm{K \alpha}$ radiation $(\lambda=1.5405 \mathrm{~nm})$ at $2 \theta$ between 35 and $85^{\circ}$.

Temperature programed reduction (TPR) was tested using an AutoChem II, 2920 Micromeritics apparatus.

Temperature programmed hydrogenation (TPH) coupled to mass spectrometry measurements were done on spent catalysts while heating from 100 to around $900^{\circ} \mathrm{C}$ (at $10^{\circ} \mathrm{C} \cdot \mathrm{min}^{-1}$ ) at atmospheric pressure under $5 \mathrm{vol} \% \mathrm{H} 2 / \mathrm{Ar}\left(30 \mathrm{ml} . \mathrm{min}^{-1}\right)$. Experiments were performed by connecting the AutoChem 2920 to an online quadrupole mass spectrometer (MKS, Cirrus 2). This technique is helpful in determining the type of deposited carbon in the spent catalyst according to its gasification temperature to $\mathrm{CH} 4: \mathrm{C} \alpha$ up to $350^{\circ} \mathrm{C}, 350<\mathrm{C} \beta$ $<500^{\circ} \mathrm{C}$ and $\mathrm{C} \gamma$ above $500^{\circ} \mathrm{C}[20]$.

A JEOL JEM-200 electron microscope operating at 200 $\mathrm{keV}$ (LaB6 gun) was used for Transmission electron microscopy (TEM) images.

\section{Catalytic testing}

Calcined catalysts were tested in a Hastelloy-X reactor (Microreactivity, PID Eng and Tech, internal diameter $9 \mathrm{~mm}$ ). $200 \mathrm{mg}$ of each catalyst were first reduced in-situ using $5 \mathrm{vol} \%$ $\mathrm{H}_{2} / \mathrm{Ar}\left(30 \mathrm{ml} \cdot \mathrm{min}^{-1}\right)$ at $650^{\circ} \mathrm{C}$ for 2 hours to ensure complete reduction of nickel oxide into $\mathrm{Ni}^{0}$ metallic nickel. After reduction, the temperature was lowered to $200^{\circ} \mathrm{C}$ and then increased from $200^{\circ} \mathrm{C}$ to about $800^{\circ} \mathrm{C}$ (at $5^{\circ} \mathrm{C} \cdot \mathrm{min}^{-1}$ ) again under an equimolar mixture of $\mathrm{CH}_{4}$ and $\mathrm{CO}_{2}$ using a gas hourly space velocity (GHSV) of $18 \mathrm{~L} \cdot \mathrm{hr}^{-1} \cdot \mathrm{g}^{-1}$. The catalytic stability was measured by keeping the reactor at $650^{\circ} \mathrm{C}$ for 12 hours. Effluent gases from the reactor were analyzed online using an Inficon micro-GC equipped with a TCD and two types of columns (molecular sieves and plot-U) to detect $\mathrm{H}_{2}, \mathrm{CH}_{4}, \mathrm{CO}$ and $\mathrm{CO}_{2}$ gases. The reactants conversions were calculated using the following equations:

$$
\begin{aligned}
& \mathrm{CH}_{4} \text { conversion }(\%)=100 \times\left[\mathrm{CH}_{4(\text { in })}-\mathrm{CH}_{4(\mathrm{out})}\right] / \mathrm{CH}_{4(\mathrm{in})} \\
& \mathrm{CO}_{2} \text { conversion }(\%)=100 \times\left[\mathrm{CO}_{2(\text { in })}-\mathrm{CO}_{2(\text { out })}\right] / \mathrm{CO}_{2(\text { in })}
\end{aligned}
$$

\section{RESULTS AND DISCUSSION}

\section{A. Structure and porosity of catalysts}

$\mathrm{N}_{2}$-sorption isotherms show a type IV isotherm for all catalysts, typical of mesoporous silica materials (data not shown). Ni/SBA-15 catalyst has H1-type hysteresis loop typical of 2-D hexagonal structure whereas both Ni/SBA-16(1) and $\mathrm{Ni} / \mathrm{SBA}-16(2)$ show an $\mathrm{H}_{2}$ hysteresis loop reflecting a cubic structure of the material with cage-like pores typical for SBA-16 parent [21].

TABLE I. BET SURFACE AREA AND CRYSTALLITE SIZE OF FRESH AND

\begin{tabular}{|c|c|c|c|}
\hline \multirow{2}{*}{ Catalyst } & \multirow{2}{*}{$\begin{array}{l}\text { BET surface area } \\
\text { from } \mathrm{N}_{2} \text { sorption } \\
\text { isotherms }\left(\mathrm{m}^{2} \cdot \mathrm{g}^{-1}\right)\end{array}$} & \multicolumn{2}{|c|}{ Crystallite size by XRD (nm) } \\
\hline & & $\begin{array}{c}\text { Fresh catalyst } \\
\text { (NiO) }\end{array}$ & $\begin{array}{c}\text { Spent catalyst } \\
\left(N i^{0}\right)\end{array}$ \\
\hline SBA-16(1) & 408 & - & - \\
\hline Ni/SBA-16(1) & 295 & 7.7 & 11 \\
\hline SBA-16(2) & 336 & - & - \\
\hline $\mathrm{Ni} / \mathrm{SBA}-16(2)$ & 138 & 7.5 & 13.2 \\
\hline SBA-15 & 701 & - & - \\
\hline Ni/SBA-15 & 528 & 3.3 & 3.6 \\
\hline
\end{tabular}
SPENT CATALYSTS

BET surface areas of the three different supports with their impregnated active phase (5wt \%) are grouped in Table I. Concerning SBA-16 supports, their surface area was in the range of 300-410 $\mathrm{m}^{2} \cdot \mathrm{g}^{-1}$ whereas SBA-15 support had much higher surface area $\left(701 \mathrm{~m}^{2} \cdot \mathrm{g}^{-1}\right)$. For all SBA based samples, the surface area was decreased after nickel impregnation which is attributed to partially filled pores or to some collapse of the silica walls. But since the shape of isotherms for the impregnated SBA stayed similar to the parent SBA, a wellorganized framework was preserved and it can be concluded that there was no destruction of support. Such destruction can take place under the preparation procedure used in this study, but the TEM images (Fig. 4(a)) prove that SBA-16 framework and pore structures remained intact, similar to the study done on DRM in [12].

$\mathrm{XRD}$ for calcined samples at wide angle $\left(35<2 \theta<85^{\circ}\right)$ are represented in Fig.1A. Fresh Ni/SBA-15/16 catalysts exhibit three main peaks at $2 \theta=37,43$ and $63^{\circ}$ (identified by -) corresponding to $\mathrm{NiO}$ particles with face centered cubic (FCC) unit cell and reticular planes respectively indexed (111), (200), (220) (JCPDS 71-4750). Based on the Scherrer equation, the mean $\mathrm{NiO}$ particle sizes of each catalyst are found to be 7.7, 7.5 and $3.3 \mathrm{~nm}$ for Ni/SBA-16(1), Ni/SBA-16(2) and Ni/SBA-15, respectively (Table I). Since all SBA based catalysts are impregnated with the same amount of nickel (5 $\% \mathrm{wt}$ ), the difference in crystallite size means that nickel particles are better dispersed over SBA-15 support than on SBA-16.

\section{B. Reducibility of Ni/SBA-16(1), Ni/SBA-16(2), and Ni/SBA- 15}

TPR profiles of reduced Ni/SBA catalysts (Fig. 2) show two hydrogen consumption peaks: a first peak between 300 and $450^{\circ} \mathrm{C}$ corresponding to free $\mathrm{NiO}$ particles easily reduced and a second peak attributable to $\mathrm{Ni}$ oxide species in strong interaction with the support and reduced at higher temperature, greater than $450^{\circ} \mathrm{C}$ [23]. With $\mathrm{Ni} / \mathrm{SBA}-15$, the main $\mathrm{NiO}$ species appear to be in enhanced interaction with the support. Whereas for Ni/SBA-16(1) and Ni/SBA-16(2), most of NiO where reduced at the lower temperature range. 


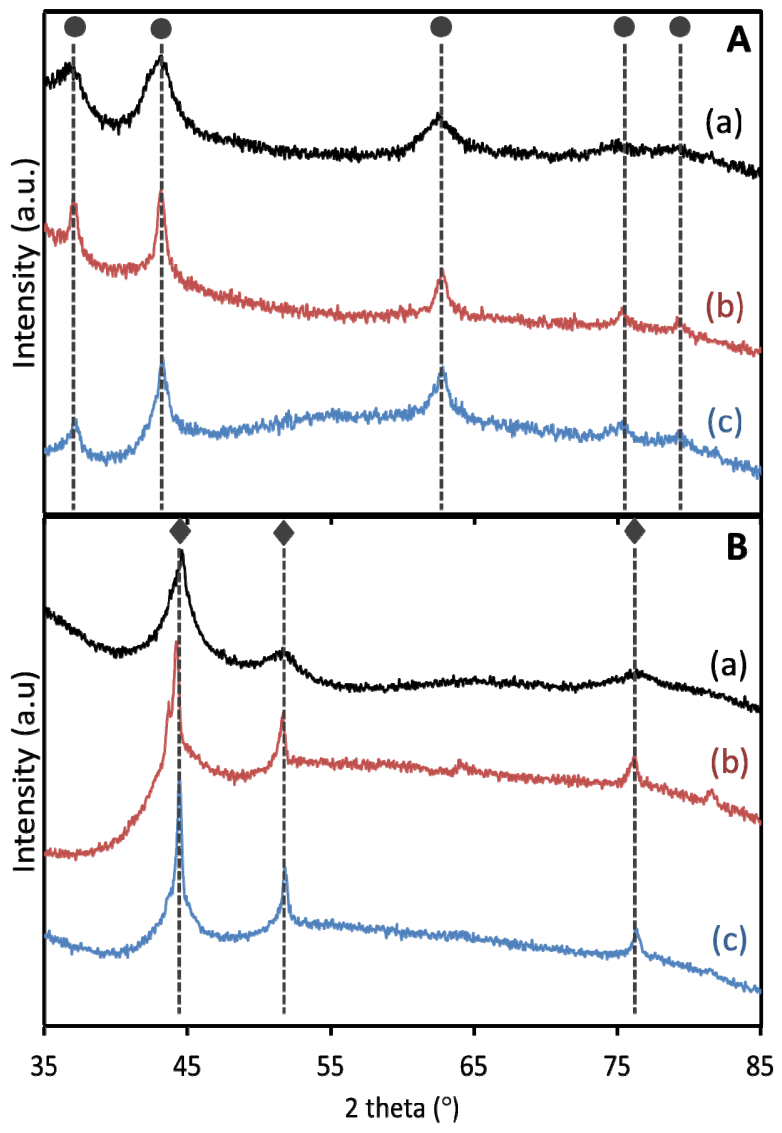

Fig. 1. X-ray diffraction patterns for (A) fresh and (B) spent catalysts (a) Ni/SBA-15, (b) Ni/SBA-16(1), (c) Ni/SBA-16(2)

This behavior could be due to the different availabilities of $\mathrm{SiO}_{2}$ surface sites especially that Ni/SBA-15 has larger surface area than both $\mathrm{Ni} / \mathrm{SBA}-16$ catalysts and thus the smaller surfaces accessible on SBA-16 might limit the formation of mixed phases upon the addition of the nickel precursor [24].

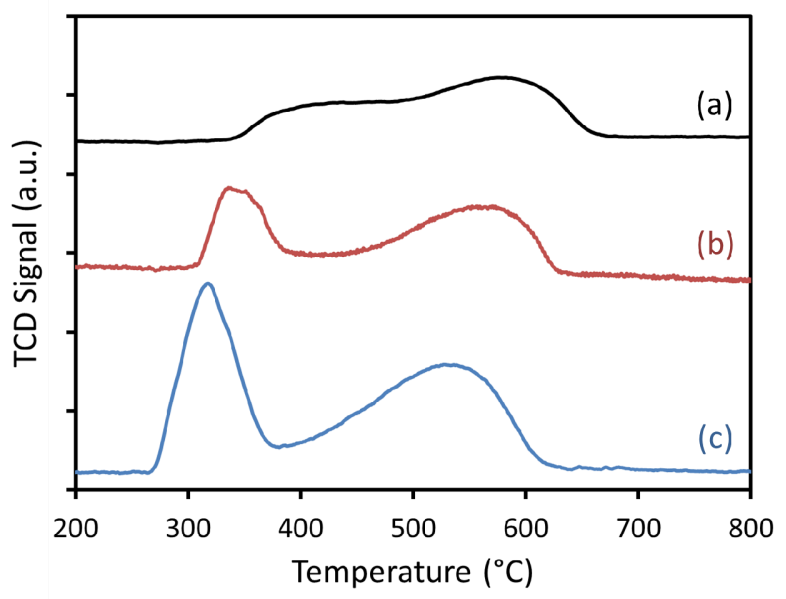

Fig. 2. TPR profiles for catalysts (a) Ni/SBA-15, (b) Ni/SBA-16(1), (c) Ni/SBA-16(2)

\section{Activity and stability in DRM}

Catalytic stability experiments (Fig. 3) were carried out at $650^{\circ} \mathrm{C}$ for 12 hours under stream. Ni/SBA-15 catalyst appears to be fully stable with preservation of $\mathrm{CH}_{4}$ and $\mathrm{CO}_{2}$ conversions (75 and $80 \%$ respectively). On the other hand, conversions on both Ni/SBA-16(1) and Ni/SBA-16(2) start at lower values than $\mathrm{Ni} / \mathrm{SBA}-15$ and are deactivation appears through time with an average conversion loss of about $20 \%$ and $30 \%$ respectively at the end of reaction. This reveals that SBA15 structure could prevent deactivation and maintain catalyst stability, not to mention that $\mathrm{CO}_{2}$ conversions remain higher than those of $\mathrm{CH}_{4}$ due to the occurrence of RWGS. Reasons behind such behaviors resulting in deactivation will be discussed in the following section.

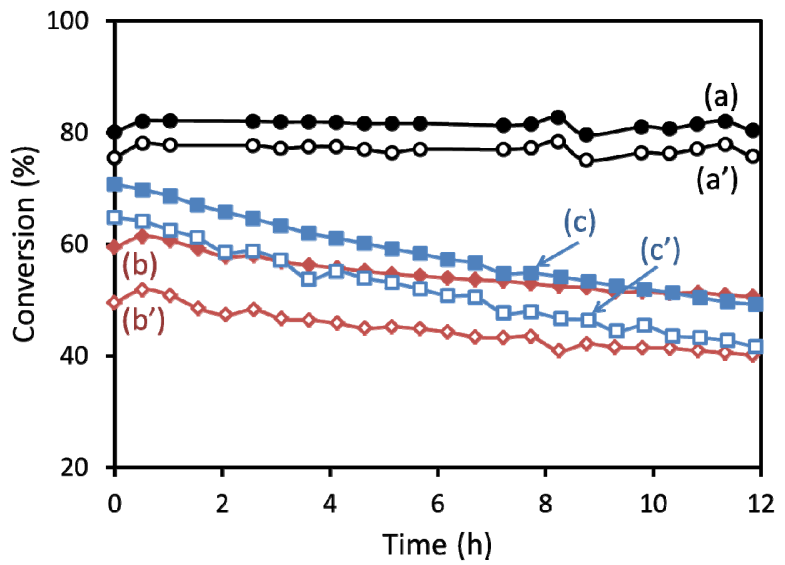

Fig. 3. Isothermal DRM experiments at $650{ }^{\circ} \mathrm{C}$ for (a-c) $\mathrm{CH}_{4}$ conversions and (a'-c') $\mathrm{CO}_{2}$ conversions: (a, a') Ni/SBA-15, (b- b') Ni/SBA-16(1), (c- c') $\mathrm{Ni} / \mathrm{SBA}-16(2)$

\section{Physicochemical properties of the spent catalysts}

To understand the reasons behind Ni/SBA-16 catalysts deactivation, XRD of spent catalysts, TEM and TPH/MS experiments were performed to check the presence of coke and/or sintering.

XRD for the 3 spent catalysts (Fig. 1(b)) show three peaks at $2 \theta=44,52$ and $76^{\circ}$ for planes (111), (200) and (220) respectively, corresponding to $\mathrm{Ni}$ metallic particles (identified by $\downarrow$, JCPDS 01-1258). This means that no re-oxidation of $\mathrm{Ni}^{0}$ due to water formation through RWGS occurred during reaction $[25,26]$ and therefore deactivation of $\mathrm{Ni} / \mathrm{SBA}-16$ is independent of this phenomenon. However, the peaks are much wider and almost invisible for Ni/SBA-15 catalyst than those for both Ni/SBA-16 catalysts that appear very intense. Table I shows that Ni particles over SBA-15 support remained small $(3.6 \mathrm{~nm})$ stressing on their high dispersion that is well retained even after test. Ni crystallite sizes for Ni/SBA-16(1) and $\mathrm{Ni} / \mathrm{SBA}-16(2)$ are 11 and $13.2 \mathrm{~nm}$ respectively which highlights the occurrence of sintering, thus destabilizing and deactivating the catalysts as seen during catalytic test.

Fig. 4(b) of spent Ni/SBA-16(1) displays extremely large $\mathrm{Ni}$ nanoparticles with some carbon deposition. The weak interaction of the $\mathrm{Ni}$ species with SBA-16 could have facilitated their migration outside the mesopores and their aggregation at the surface at high temperature (compared to 
fresh ones, data not shown), thus reducing stability and catalytic performance [27]. However, on Ni/SBA-15 (Fig. 4(c)), Ni nanoparticles are still confined inside the pores with no migration to the external surface even after 12 hours under stream. In addition to this, Ni/SBA-15 shows high level of $\mathrm{Ni}$ dispersion that is restrained also after test which is in agreement with the small size of Ni particles $(3.6 \mathrm{~nm})$ obtained by XRD. Based on these findings and on TPR experiments, Ni species strongly interacting with the support can influence the catalytic stability of $\mathrm{Ni} / \mathrm{SBA}-15$. Therefore these catalysts were more stable and showed high resistance towards particles sintering, regardless of the coke formation that will be further elaborated in TPH experiments.
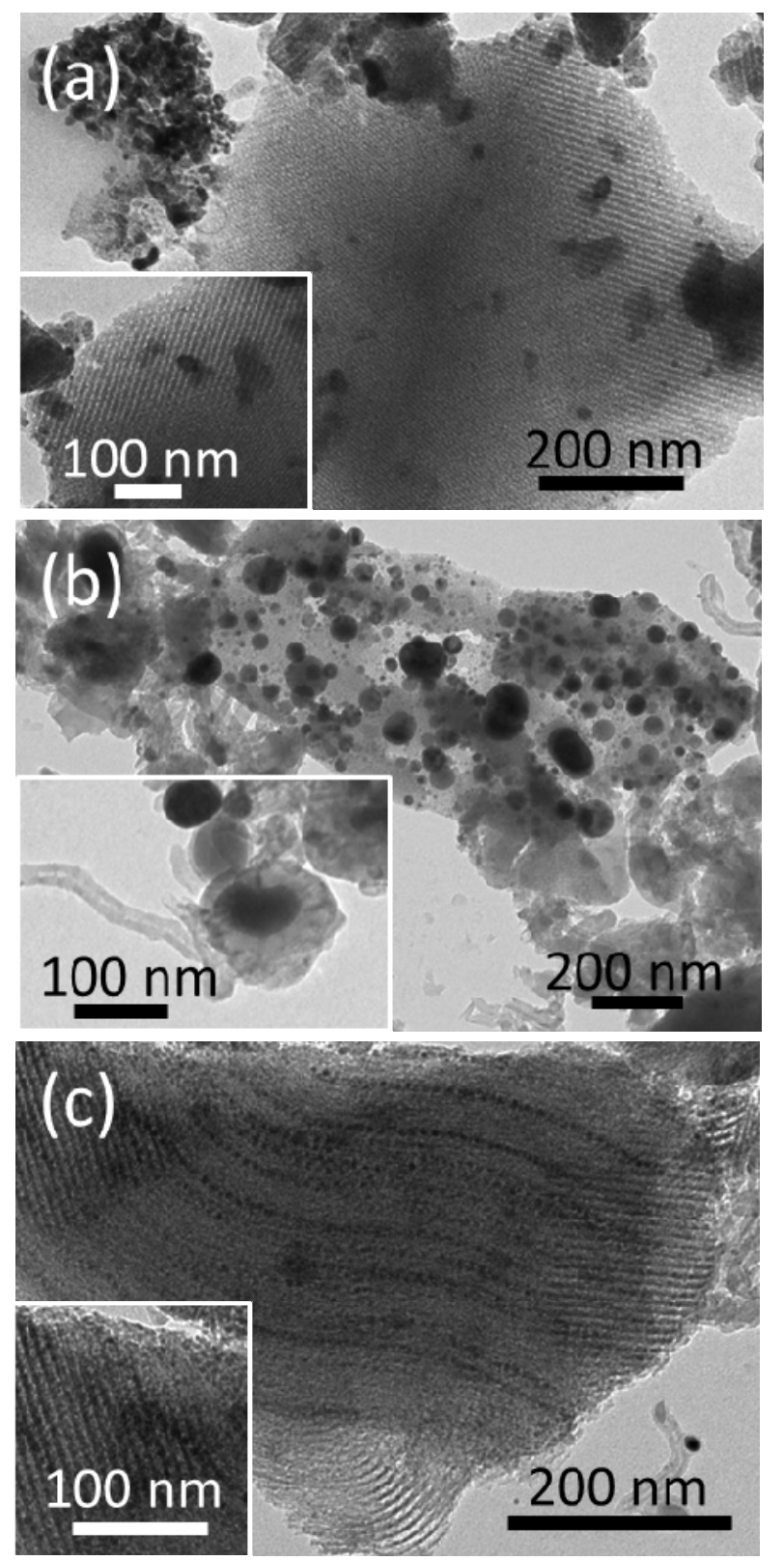

Fig. 4. TEM images of (a) calcined Ni/SBA-16(1) and spent (b) Ni/SBA-16(1), (c) Ni/SBA-15

In addition to metal sintering effect, coke formation might also have certain impact on catalysts behavior. TPH/MS experiments applied on the different spent catalysts determine the types of carbon deposits (Fig. 5). These experiments rely on the temperature at which methane $(\mathrm{m} / \mathrm{z}=16)$ is formed by hydrogenation of carbon species $\mathrm{H}_{2}$ consumption.

From the three types of carbon discussed earlier, $\mathrm{C} \alpha$ is a reactive intermediate that does not have influence on catalyst stability; $C \beta$ represents nanotubes and $C \gamma$, a graphitic carbon, which is the most detrimental type responsible of catalyst deactivation [20,28,29]. Fig. 5 shows that Ni/SBA-15 catalyst (Fig. 5 (a)) contains the highest amount of carbon among others, but it is the only catalyst carrying the least amount of $\mathrm{C} \gamma$ and the highest amount of $\mathrm{C} \alpha$ carbon. $\mathrm{C} \alpha$ is expected to be produced from thermal decomposition of methane and can lead after to the formation of $\mathrm{CO}$ by hydrogenation at low temperature [30]. Therefore, even if present at high concentrations, its effect is benign on catalyst performance and activity and this is emphasized by the high stability of Ni/SBA15 during time on stream. Such behavior is also elaborated in a study done by Igor Luisetto et al. [31] where they show that $\mathrm{Ni} / \mathrm{CeO}_{2}-\mathrm{Al}_{2} \mathrm{O}_{3}$ prepared by co-precipitation method was highly active and stable in spite of the greater carbon deposition on its surface and related this behavior to the fact that $\mathrm{C} \alpha$ does not encapsulate $\mathrm{Ni}^{0}$ sites which remain accessible to the reactants.

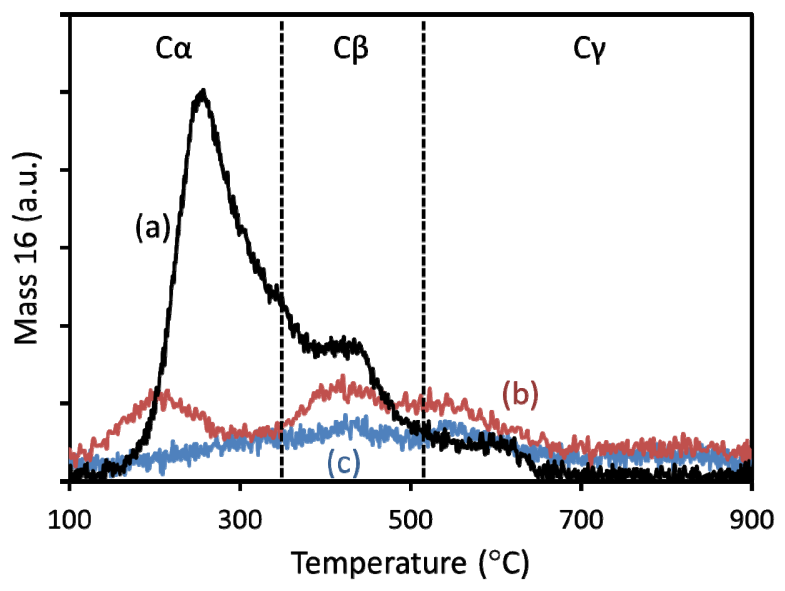

Fig. 5. TPH profiles for catalysts (a) Ni/SBA-15, (b) Ni/SBA-16(1), (c) $\mathrm{Ni} / \mathrm{SBA}-16(2)$

Thus, the main cause behind catalysts deactivation of $\mathrm{Ni} / \mathrm{SBA}-16$ is attributed to sintering, weak of metal-support interaction and low nickel dispersion as shown in [32]. It is important to mention that even if carbon formation does not alter catalyst performance, its mitigation and removal is a must because it can accumulate with time leading to reactor plugging and reaction perturbation.

\section{CONCLUSION}

In this study, $5 \mathrm{wt} \% \mathrm{Ni}$ were impregnated on commercial SBA-15 and synthesized SBA-16 supports and the properties of the resulting samples in addition to their catalytic performances were compared. While the SBA-15 2D hexagonal structure permits the stabilization of nickel inside the pores, SBA-16 cubic structure was not ideal for dispersion of nickel inside the pores nor for their stabilization under 
methane dry reforming. Ni/SBA-15 (without any promoter) are promising for DRM in opposition to $\mathrm{Ni} / \mathrm{SBA}-16$ catalysts where sintering is leading to rapid deactivation of the catalysts under stream.

\section{ACKNOWLEDGMENT}

Authors would like to acknowledge the help of Mrs. Hala Fallah in the XRD experiments.

\section{REFERENCES}

[1] M. F. Mark, W. F. Maier, " $\mathrm{CO}_{2}$-reforming of methane on supported $\mathrm{Rh}$ and Ir catalysts. J. Catal., vol. 164, pp. 122-130, 1996.

[2] V. Y. Bychkov, O. V. Krylov, V. N. Korchak, "The Mechanistic Study of Methane Reforming with Carbon Dioxide on $\mathrm{Ni} / \alpha-\mathrm{Al}_{2} \mathrm{O}_{3}$ ", Kinet. Catal., vol. 43, pp. 86-94, 2012.

[3] J. L. Pinilla, I. Suelves, M. J. Lázaro, R. Moliner, J. M. Palacios, "Influence of nickel crystal domain size on the behaviour of $\mathrm{Ni}$ and $\mathrm{NiCu}$ catalysts for the methane decomposition reaction", Appl. Catal., A, vol. 363, pp. 199-207, 2009.

[4] M. Rezaei, S. M. Alavi, S. Sahebdelfar, Z. F. Yan, "Syngas production by methane reforming with carbon dioxide on noble metal catalysts", J. Nat. Gas Chem., vol. 15, pp. 327-334, 2006.

[5] J. Zhu, X. Peng, L. Yao, J. Shen, D. Tong, C. Hu, "The promoting effect of $\mathrm{La}, \mathrm{Mg}, \mathrm{Co}$ and $\mathrm{Zn}$ on the activity and stability of $\mathrm{Ni} / \mathrm{SiO}_{2}$ catalyst for $\mathrm{CO}_{2}$ reforming of methane", Int. J. Hydrogen Energy, vol. 36, pp. 70947104, 2011.

[6] Z. Alipour, M. Rezaei, F. Meshkani, "Effect of alkaline earth promoters $(\mathrm{MgO}, \mathrm{CaO}$, and $\mathrm{BaO})$ on the activity and coke formation of $\mathrm{Ni}$ catalysts supported on nanocrystalline $\mathrm{Al}_{2} \mathrm{O}_{3}$ in dry reforming of methane", J. Ind. Eng. Chem., vol. 20, pp. 2858-2863, 2014.

[7] S. Yasyerli, S. Filizgok, H. Arbag, N. Yasyerli, G. Dogu, "Ru incorporated Ni-MCM-41 mesoporous catalysts for dry reforming of methane: Effects of $\mathrm{Mg}$ addition, feed composition and temperature", Int. J. Hydrogen Energy, vol. 36, pp. 4863-4874, 2011.

[8] D. Liu, X. Y. Quek, W. N. E. Cheo, R. Lau, A. Borgna, Y. Yang, "MCM-41 supported nickel-based bimetallic catalysts with superior stability during carbon dioxide reforming of methane: Effect of strong metal-support interaction", J. Catal., vol. 266, pp. 380-390, 2009.

[9] S. K. Talkhoncheh, M. Haghighi, "Syngas production via dry reforming of methane over Ni-based nanocatalyst over various supports of clinoptilolite, ceria and alumina", J. Nat. Gas Sci. Eng., vol. 23, pp. 1625, 2015.

[10] M. N. Kaydouh, N. El Hassan, A. Davidson, S. Casale, H. El Zakhem, P. Massiani, "Highly active and stable Ni/SBA-15 catalysts prepared by a "two solvents" method for dry reforming of methane", Microporous Mesoporous Mater., vol. 220, pp. 99-109, 2016.

[11] L. Karam, S. Casale, H. El Zakhem, N. El Hassan, "Tuning the properties of nickel nanoparticles inside SBA-15 mesopores for enhanced stability in methane reforming", J. $\mathrm{CO}_{2}$ Utilization, vol. 17, pp. 119-124, 2017.

[12] S. Zhang, S. Muratsugu, N. Ishiguro, M. Tada, M., "Ceria-doped Ni/SBA-16 catalysts for dry reforming of methane", ACS Catal., vol. 3, pp. 1855-1864, 2013.

[13] C. Jeffrey Brinker, Y. Lu, A. Sellinger, H. Fan, "Evaporation-Induced Self-Assembly: Nanostructures Made Easy", Adv. Mater., vol. 11, No.7, pp. 579-585, 1999.

[14] D. Grosso, F. Cagnol, G. J. de A. A. Soler-Illia, E. L. Crepaldi, H. Amenitsch, A. Brunet-Bruneau, A. Bourgeois, C. Sanchez, "Fundamentals of Mesostructuring Through Evaporation-Induced SelfAssembly", Advanced Functional Materials, vol. 14(4), pp. 309-322, 2004.

[15] W. Hamd, S. Cobo, J. Fize, G. Baldinozzi, W. Schwartz, M. Reymermier, A. Pereira, M. Fontecave, V. Artero, C. Laberty-Robert, C.
Sanchez, "Mesoporous $\alpha-\mathrm{Fe}_{2} \mathrm{O}_{3}$ thin films synthesized via the sol-gel process for light-driven water oxidation", Phys. Chem. Chem. Phys., vol. 14, pp. 13224-13232, 2012.

[16] W. Hamd, M. Chavarot-Kerlidou, J. Fize, G. Muller, A. Leyris, M. Matheron, E. Courtin, M. Fontecave, C. Sanchez, V. Arterob, C. Laberty-Robert, "Dye-sensitized nanostructured crystalline mesoporous tin-doped indium oxide films with tunable thickness for photoelectrochemical applications", J. Mater. Chem. A, vol. 1, pp. 8217$8225,2013$.

[17] C. F. Cheng, Y. C. Lin, H. H. Cheng, Y. C. Chen, "The effect and model of silica concentrations on physical properties and particle sizes of threedimensional SBA-16 nanoporous materials", Chem. Phys. Lett., vol. 382, pp. 496-501, 2003.

[18] S. M. L. dos Santos, K. A. B. Nogueira, M. de Souza Gama, J. D. F. Lima, I. J. da Silva Júnior, D. C. S. de Azevedo, "Synthesis and characterization of ordered mesoporous silica (SBA-15 and SBA-16) for adsorption of biomolecules", Microporous Mesoporous Mater., vol. 180, pp. 284-292, 2013.

[19] I. Lopes, N. El Hassan, H. Guerba, G. Wallez, A. Davidson, "Sizeinduced structural modifications affecting $\mathrm{Co}_{3} \mathrm{O}_{4}$ nanoparticles patterned in SBA-15 silicas", Chem. Mater., vol. 18, pp. 5826-5828, 2006.

[20] K. Jabbour, N. El Hassan, A. Davidson, P. Massiani, S. Casale, "Characterizations and performances of $\mathrm{Ni} /$ diatomite catalysts for dry reforming of methane", Chem. Eng. J., vol. 264, pp. 351-358, 2015.

[21] M. Thommes, K. Kaneko, A. V. Neimark, J. P. Olivier, F. RodriguezReinoso, J. Rouquerol, K. S. Sing, "Physisorption of gases, with special reference to the evaluation of surface area and pore size distribution (IUPAC Technical Report)", Pure Appl. Chem., vol. 87, pp. 1051-1069, 2015.

[22] M. Kruk, C. M. Hui, "Thermally induced transition between open and closed spherical pores in ordered mesoporous silicas", J. Am. Chem. Soc., vol. 130, pp.1528-1529, 2008.

[23] T. Xie, L. Shi, J. Zhang, D. Zhang, "Immobilizing Ni nanoparticles to mesoporous silica with size and location control via a polyol-assisted route for coking-and sintering-resistant dry reforming of methane", Chem. Commun., vol. 50, pp. 7250-7253, 2014.

[24] J. A. C. Dias, J. M. Assaf, "Influence of calcium content in $\mathrm{Ni} / \mathrm{CaO} / \gamma$ $\mathrm{Al}_{2} \mathrm{O}_{3}$ catalysts for $\mathrm{CO}_{2}$-reforming of methane", Catal. Today, vol. 85, pp. 59-68, 2003.

[25] C. Zhang, W. Zhu, S. Li, G. Wu, X. Ma, X. Wang, J. Gong, "Sinteringresistant Ni-based reforming catalysts obtained via the nanoconfinement effect", Chem. Commun., vol. 49, pp. 9383-9385, 2013.

[26] B. Huang, X. Li, S. Ji, B. Lang, F. Habimana, C. Li, "Effect of MgO promoter on Ni-based SBA-15 catalysts for combined steam and carbon dioxide reforming of methane", J. Nat. Gas Chem., vol. 17, pp. 225-231, 2008.

[27] D. Kantorovich, L. Haviv, L. Vradman, M. V. Landau, "Behaviour of $\mathrm{NiO}$ and $\mathrm{Ni}^{0}$ phases at high loadings, in SBA-15 and SBA-16 mesoporous silica matrices", Stud. Surf. Sci. Catal., vol. 156, pp. 147154, 2005.

[28] S. Zhang, S. Muratsugu, N. Ishiguro, M. Tada, "Ceria-doped Ni/SBA-16 catalysts for dry reforming of methane", ACS Catal., vol. 3, pp. 18551864, 2013.

[29] Z. L. Zhang, X. E. Verykios, "Carbon dioxide reforming of methane to synthesis gas over supported Ni catalysts", Catal. Today, vol. 21, pp. 589-595, 1994.

[30] Y. G. Chen, K. Tomishige, K. Fujimoto, "Formation and characteristic properties of carbonaceous species on nickel-magnesia solid solution catalysts during $\mathrm{CH}_{4} \mathrm{CO}_{2}$ reforming reaction", Appl. Catal., A, vol. 161, pp. L11-L17, 1997.

[31] I. Luisetto, S. Tuti, C. Battocchio, S.L. Mastro, A. Sodo, "Ni/CeO $\mathrm{Al}_{2} \mathrm{O}_{3}$ catalysts for the dry reforming of methane: The effect of $\mathrm{CeAlO}_{3}$ content and nickel crystallite size on catalytic activity and coke resistance", Appl. Catal., A, vol. 500, pp. 12-22, 2015.

[32] M. M. Nair, S. Kaliaguine, "Structured catalysts for dry reforming of methane", New J. Chem., vol. 40, pp. 4049-4060, 2016. 